\title{
PENGARUH MANAJEMEN LABA, PROPORSI KOMISARIS INDEPENDEN, PROFITABILITAS, CAPITAL INTENSITY, DAN LIKUIDITAS TERHADAP TAX AGGRESSIVENESS (STUDI EMPIRIS PADA PERUSAHAAN MANUFAKTUR YANG TERDAFTAR DI BURSA EFEK INDONESIA TAHUN 2012-2016)
}

\author{
Leem Sufia ${ }^{1}$, Ernie Riswandari ${ }^{2}$ \\ Universitas Bunda Mulia \\ sufia_lim@yahoo.com ${ }^{1}$, eriswandari@bundamulia.ac.id ${ }^{2}$
}

\begin{abstract}
Taxes are the main source of state revenue. The greater amount of tax revenue attainment can support the national economy. However, on the other hand, taxes are a burden that can reduce income for taxpayer. This encourage taxpayer to make every effort to reduce the tax burden from legal tax planning to illegal. Excessive tax planning will result to tax aggressiveness. This study aims to examine, analyse, and obtain empirical evidence about the effect of earnings management, proportion of independent commissioners, profitability, capital intensity, and liquidity to tax aggressiveness. This research is also to compare the result of prior researches. The population in this research is 144 manufacturing companies that listed in Indonesian Stock Exchange from 2012 to 2016. Sample consist of 51 manufacturing companies, selected using one of nonprobability sampling method, which is purposive sampling type. The data type is secondary data which collected from IDX website. The statistical method used in this research is multiple regression analysis. These results indicates that earnings management and profitability have a significant influence to tax aggressiveness. While the proportion of independent commissioners, capital intensity, dan liquidity have no influence toward tax aggressiveness. But, if earnings management, proportion of independent commissioners, profitability, capital intensity, and liquidity simultantly tested with the control variable which are size and leverage the result show that there is significant association with the tax aggressiveness.
\end{abstract}

Keyword : Tax aggressiveness, earnings management, proportion of independent commissioners, profitability, capital intensity, liquidity, size, leverage.

\begin{abstract}
ABSTRAK: Pajak merupakan sumber utama penerimaan negara. Semakin besar jumlah penerimaan pajak maka dapat mendukung perekonomian nasional. Namun, di sisi lain, pajak merupakan beban yang dapat mengurangi penghasilan bagi wajib pajak. Hal ini mendorong wajib pajak untuk melakukan segala upaya untuk menekan beban pajak mulai dari perencanaan pajak yang legal hingga ilegal. Perencanaan pajak yang berlebihan akan menimbulkan agresivitas pajak. Penelitian ini bertujuan untuk menguji, menganalisis, dan memperoleh bukti empiris mengenai pengaruh manajemen laba, proporsi komisaris independen, profitabilitas, capital intensity, dan likuiditas terhadap tax aggressiveness. Penelitian ini juga membandingkan hasil dengan penelitian sebelumnya. Populasi dari penelitian ini adalah 144 perusahaan manufaktur yang terdaftar di Bursa Efek Indonesia dari tahun 2012 sampai dengan 2016. Sampel terdiri dari 51 perusahaan manufaktur yang dipilih menggunakan salah satu metode nonprobability sampling, yaitu tipe purposive sampling. Tipe data adalah data sekunder yang diperoleh dari situs IDX. Metode statistik yang digunakan adalah analisis regresi berganda. Hasil penelitian menunjukkan bahwa manajemen laba dan profitabilitas berpengaruh signifikan terhadap tax aggressiveness. Sedangkan proporsi komisaris independen, capital intensity, dan likuiditas tidak berpengaruh terhadap tax aggressiveness. Namun, jika manajemen laba, proporsi komisaris independen, profitabilitas, capital intensity, dan likuiditas diuji secara bersama-sama dengan variabel kontrol, yaitu ukuran perusahaan dan leverage menunjukkan terdapat pengaruh terhadap tax aggressiveness.
\end{abstract}

Kata kunci: Agresivitas pajak, manajemen laba, proporsi komisaris independen, profitabilitas, capital intensity, likuiditas, ukuran perusahaan, leverage. 


\section{Pendahuluan}

\subsection{Latar Belakang}

Tujuan setiap perusahaan dalam melakukan aktivitas bisnis tidak lain adalah untuk mencapai tingkat laba yang semaksimal mungkin sehingga melakukan berbagai upaya untuk mewujudkannya. Namun, di sisi lain, perusahaan sebagai wajib pajak harus taat pada peraturan perpajakan yang berlaku sebagaimana dijelaskan dalam Undang-Undang KUP No. 28 Tahun 2007 Pasal 1 ayat (1) bahwa "Pajak adalah kontribusi wajib kepada negara yang terutang oleh orang pribadi atau badan yang bersifat memaksa berdasarkan UndangUndang, dengan tidak mendapatkan imbalan secara langsung dan digunakan untuk keperluan negara bagi sebesarbesarnya kemakmuran rakyat." Hal ini menjadi dilema bagi perusahaan karena tidak sesuai dengan tujuan yang ingin dicapai perusahaan. Terlebih lagi, saat ini di Indonesia, sumber Anggaran Pendapatan dan Belanja Negara (APBN) didominasi oleh penerimaan pajak. Peningkatan penerimaan di sektor pajak tidak diimbangi oleh tingkat kepatuhan wajib pajak. Hingga tahun 2015, Wajib Pajak (WP) Badan yang terdaftar dalam sistem administrasi Direktorat Jenderal Pajak (DJP) mencapai 2.472.632 WP Badan dengan jumlah WP Badan yang wajib SPT sebesar 1.184.816 WP Badan, tetapi yang menyampaikan SPT Tahunan hanya sebesar 676.405 WP Badan yang mengartikan bahwa tingkat atau rasio kepatuhan WP Badan baru mencapai 57,09\% (www.pajak.go.id).

Sistem pemungutan pajak penghasilan badan yang berlaku di Indonesia menganut self assessment system. Dengan demikian, berhasil atau tidaknya pelaksanaan pemungutan pajak banyak tergantung pada wajib pajak sendiri (Resmi, 2017, p11). Perusahaan akan memilih untuk melakukan tindakan pajak agresif dengan tujuan menekan beban pajak serendah-rendahnya. Fenomena terbaru yang terjadi saat ini adalah penghindaran pajak yang dilakukan oleh Google. Sejak hadir di Indonesia pada tahun 2011, Google tidak pernah membayar pajak. Agar terhindar dari pajak, Google mentransfer dana ke tax haven country, yaitu Singapura. Hal ini mengakibatkan kerugian bagi negara yang menjadi tempat bagi Google untuk mendapatkan penghasilan namun tidak membayar pajak sesuai dengan peraturan (Yusuf, 2016). Tax planning yang agresif sangat merugikan negara dan tergolong unacceptable tax avoidance. Contoh perusahaan di Indonesia yang memanfaatkan tax haven adalah PT Asian Agri (AAG). PT Asian Agri merekayasa penjualan produknya ke luar negeri untuk mengubah harga jual yang seharusnya ke End Buyer diganti dengan harga yang lebih rendah ke paper company di Hong Kong sehingga keuntungan menjadi lebih rendah di Indonesia. Hasilnya, pajak yang dibayar ke negara menjadi kecil dan merugikan negara dalam rangka kegiatan memperkaya diri sendiri atau perusahaan (Saputro, 2015, p50-51). PT Rajawali Nusantara Indonesia (PT RNI) yang terafiliasi dengan perusahaan di Singapura menggunakan banyak modus mulai dari administrasi hingga kegiatan yang dilakukan untuk menghindari kewajiban pajak, yaitu (Suryowati, 2016):

1. Dari segi permodalan, perusahaan menggantungkan hidup dari utang afiliasi. Afiliasi dari Singapura tidak menanamkan modalnya, namun memberikan seolah-olah seperti utang. Modal dimasukkan sebagai utang untuk mengurangi pajak sehingga perusahaan terhindar dari kewajiban perpajakan.

2. Dari segi laporan keuangan, laporan keuangan disajikan dengan tidak logis. Dalam laporan keuangan tahun 2014, tercatat utang sebesar Rp 20,4 miliar. Sementara, omset perusahaan hanya sebesar Rp 2,178 miliar dan terdapat kerugian ditahan sebesar $\mathrm{Rp}$ 26,12 miliar.

3. Memanfaatkan PP 46/2013 tentang Pajak Penghasilan khusus UMKM yang sebenarnya tidak etis untuk dimanfaatkan oleh PMA (Penanaman Modal Asing).

Pelaporan pajak agresif adalah tindakan manipulasi untuk mengurangi penghasilan kena pajak melalui perencanaan pajak yang dapat atau tidak dapat dipertimbangkan sebagai penghindaran pajak secara menyimpang (fraudulent tax evasion) (Frank et al, 2009). Ketika menentukan 
agresivitas pajak, manajer akan melakukan trade off antara biaya dan manfaat. Manfaat yang paling nyata dari agresivitas pajak adalah penghematan pajak dalam jumlah yang besar (Chen et al., 2010). Di samping itu, juga terdapat kerugian dari agresivitas pajak berupa sanksi atau pinalti dari fiskus pajak dan harga saham perusahaan menurun (Sari dan Martani, 2010).

Tiaras dan Wijaya (2015) meneliti pengaruh likuiditas, leverage, manajemen laba, komisaris independen dan ukuran perusahaan terhadap agresivitas pajak. Penelitian tersebut secara statistik menunjukkan bahwa manajemen laba dan ukuran perusahaan memiliki pengaruh yang signifikan terhadap tingkat agresivitas pajak perusahaan sedangkan likuiditas, leverage, dan komisaris independen tidak menunjukkan pengaruh yang signifikan terhadap tingkat agresivitas pajak perusahaan. Penelitian ini merupakan pengembangan dari penelitian yang dilakukan oleh Tiaras dan Wijaya (2015) dengan menambahkan dua variabel baru, yaitu profitabilitas dan capital intensity. Variabel ukuran perusahaan dan leverage yang merupakan variabel independen pada penelitian sebelumnya dijadikan variabel kontrol. Variabel kontrol dalam penelitian digunakan dalam rangka meningkatkan validitas internal hasil penelitian (Ratmono dan Sagala, 2015).

Salah satu motivasi manajer melakukan manajemen laba adalah motivasi pajak, bahwa perusahaan yang menginginkan penyajian laporan fiskal yang lebih rendah dari nilai yang sebenarnya memotivasi manajer untuk melakukan manajemen laba agar seolah-olah laba fiskal yang dilaporkan memang lebih rendah tanpa melanggar aturan dan kebijakan akuntansi perpajakan (Sulistiawan et al., 2011, p3137). Penelitian yang dilakukan oleh Kusuma dan Firmansyah (2017), Novitasari (2017), Tiaras dan Wijaya (2015), serta Suyanto dan Supramono (2012) menunjukkan bahwa manajemen laba berpengaruh positif signifikan terhadap agresivitas pajak. Sedangkan penelitian yang dilakukan oleh Amril et al. (2015) menunjukkan bahwa manajemen laba tidak berpengaruh terhadap agresivitas pajak.
Zemzem dan Ftouhi (2013) menyatakan komisaris independen dapat meningkatkan kemampuan dewan untuk memantau manajemen secara efektif dalam situasi yang ditandai oleh masalah keagenan yang timbul dari pemisahan kepemilikan, pengendalian, dan dapat membantu mengurangi agresivitas pajak. Penelitian yang dilakukan oleh Suyanto dan Supramono (2012) serta Tiaras dan Wijaya (2015) menunjukkan bahwa proporsi komisaris independen berpengaruh negatif dan signifikan terhadap agresivitas pajak. Sedangkan penelitian yang dilakukan oleh Kusuma dan Firmansyah (2017) serta Hadi dan Mangonting (2014) menunjukkan bahwa proporsi komisaris independen tidak berpengaruh terhadap agresivitas pajak.

Profitabilitas mencerminkan kemampuan perusahaan dalam menghasilkan laba. Profitabilitas dianggap sebagai variabel yang dapat menjelaskan beban pajak. Penelitian yang dilakukan oleh Zemzem dan Ftouhi (2013) serta Rodriguez dan Arias (2014) menunjukkan bahwa return on assets memiliki pengaruh negatif terhadap agresivitas pajak. Sedangkan penelitian yang dilakukan oleh Hartadinata dan Tjaraka (2013), Boussaidi dan Hamed (2015), Jessica dan Toly (2014), serta Hadi dan Mangonting (2014) menunjukkan bahwa return on assets memiliki pengaruh yang tidak signifikan terhadap agresivitas pajak.

Capital intensity berhubungan dengan agresivitas pajak karena akumulasi depresiasi yang disesuaikan dengan masa aset (Gupta dan Newberry, 1997 dalam Jessica dan Toly, 2014). Penelitian yang dilakukan oleh Jessica dan Toly (2014) menunjukkan bahwa capital intensity memiliki pengaruh positif terhadap agresivitas pajak. Sedangkan penelitian yang dilakukan oleh Hartadinata dan Tjakara (2013) serta Novitasari (2017) menunjukkan bahwa capital intensity tidak memiliki pengaruh terhadap agresivitas pajak.

Likuiditas sebuah perusahaan diprediksi akan mempengaruhi agresivitas pajak perusahaan (Suyanto dan Supramono, 2012). Penelitian yang dilakukan oleh Bradley (1994) dan Siahaan (2005) dalam 
Suyanto dan Supramono (2012) menyatakan bahwa perusahaan yang mengalami kesulitan likuiditas kemungkinan tidak akan mematuhi peraturan perpajakan dan cenderung melakukan penghindaran pajak. Sedangkan penelitian yang dilakukan oleh Suyanto dan Supramono (2012) menunjukkan bahwa likuiditas tidak berpengaruh terhadap agresivitas pajak.

Ukuran perusahaan merupakan karakteristik perusahaan yang turut mempengaruhi hasil pajak penghasilan yang akan dibayar (Hartadinata dan Tjakara, 2013). Semakin besar ukuran perusahaan maka akan semakin rendah ETR yang dimiliki yang disebabkan perusahaan mampu menggunakan sumber daya yang dimilikinya untuk membuat suatu perencanaan pajak yang baik, namun perusahaan tidak selalu dapat menggunakan power yang dimilikinya untuk melakukan perencanaan pajak karena adanya batasan berupa kemungkinan menjadi sorotan dan sasaran dari keputusan regulator, oleh karena itu ukuran perusahaan dikontrol (Hidayanti, 2013 dalam Hadi dan Mangonting, 2014).

Leverage merupakan salah satu rasio keuangan, yaitu rasio solvabilitas yang merupakan kemampuan perusahaan untuk membayar utang jangka panjang, baik utang pokok maupun bunganya. Penggunaan utang oleh perusahaan akan menimbulkan adanya bunga yang harus dibayar (Hadi dan Mangonting, 2014). Beban bunga atas utang merupakan pengurang tarif pajak efektif sehingga perusahaan dengan tingkat leverage yang tinggi akan memiliki nilai ETR yang rendah (Richardson dan Lanis, 2007). Di Indonesia, untuk mencegah praktik pemanfaatan celah-celah peraturan pajak, Menteri Keuangan telah mengeluarkan PMK No. 169/PMK 010/2015 yang mengatur besarnya biaya utang yang diperbolehkan sebagai deductible expense. Oleh karena itu, variabel leverage dikontrol.

Dalam penelitian ini, peneliti mengambil perusahaan manufaktur karena perusahaan manufaktur memiliki aset tetap dalam jumlah besar yang kebijakan akuntansi terkait penyusutan aset tetap akan menunjukkan efek kebijakan perpajakan wajib pajak badan secara signifikan (Hartadinata dan Tjakara, 2013). Selain itu, perusahaan manufaktur juga termasuk perusahaan yang mendominasi dalam Bursa Efek Indonesia dan dalam besarnya jumlah penerimaan negara dari sektor pajak. Bahkan, pada tahun 2013 diungkapkan bahwa perusahaan asing tidak membayar pajak selama tujuh tahun dengan menggeser barang produksi ke tax haven country (Muttaqin, 2016). Hal ini mengindikasikan bahwa masih terdapat sejumlah besar perusahaan manufaktur yang melakukan agresivitas pajak.

Penelitian ini mengadopsi pendekatan tidak langsung untuk mengukur variabel dependen tax aggressiveness perusahaan dalam membayar pajaknya, dengan menggunakan proksi Effective Tax Rate (ETR). ETR digunakan untuk mengukur tarif pajak perusahaan karena pajak perusahaan dibayar dengan tarif yang sama namun ETR dapat berbeda secara signifikan karena pembebasan pajak yang ditentukan oleh undang-undang perpajakan (Mladineo dan Susak, 2016). ETR juga banyak digunakan dalam penelitian sebagai proksi tax aggressiveness di antaranya penelitian yang dilakukan oleh Boussaidi dan Hamed (2015), Amril et al. (2015), Tiaras dan Wijaya (2015), Jessica dan Toly (2014), Hadi dan Mangonting (2014), Zemzem dan Ftouhi (2013), serta Hartadinata dan Tjaraka (2013). Pengukuran agresivitas pajak perusahaan dengan proksi Effective Tax Rate (ETR) dilakukan dalam periode waktu lima tahun berturut-turut untuk mengendalikan masalah pembayaran pajak yang mencakup pembayaran terpisah (ke dan pengembalian uang dari) fiskus dan otoritas pajak lainnya (Dryeng et al., 2008 dalam Minnick dan Noga, 2010) serta mencakup pajak tangguhan.

\subsection{Identifikasi Masalah}

Berdasarkan pemaparan latar belakang di atas, selanjutnya dapat diidentifikasi permasalahan dalam penelitian ini antara lain:

1. Penerimaan pajak sebagai sumber APBN walaupun terlihat meningkat dari 
tahun ke tahun namun masih belum mencapai target yang diharapkan.

2. Dari kasus PT RNI yang menyajikan laporan keuangan secara tidak logis dapat diketahui bahwa masih terdapat perusahaan yang melakukan manajemen laba dengan tujuan untuk mengecilkan beban pajak sehingga dapat diidentifikasi bahwa manajemen laba diprediksi menjadi cara yang jitu bagi wajib pajak untuk melakukan agresivitas pajak.

3. Terjadi rekayasa penjualan produk ke luar negeri dengan mengubah harga jual yang seharusnya yang dilakukan oleh PT Asian Agri menunjukkan bahwa masih terdapat perusahaan yang memainkan profit untuk menghindari kewajiban pembayaran pajak yang seharusnya. Hal ini mengindikasikan bahwa profitabilitas dijadikan sarana untuk melakukan agresivitas pajak.

4. PT Google Indonesia yang tidak membayar pajak penghasilan sejak tahun 2011 yang telah memperoleh penghasilan di Indonesia membuktikan bahwa masih terdapat komisaris independen yang belum menjalankan tanggung jawabnya dengan optimal. Oleh karena itu proporsi komisaris independen diprediksi dapat mempengaruhi agresivitas pajak yang dilakukan oleh perusahaan.

5. Perusahaan memiliki capital intensity terutama perusahaan manufaktur untuk kegiatan operasional, juga memiliki likuiditas untuk memenuhi kewajiban jangka pendeknya. Proporsi capital intensity dan likuiditas dalam jumlah besar diprediksi dapat menjadi faktor bagi perusahaan untuk melakukan agresivitas pajak melalui pemilihan kebijakan akuntansi atas pencatatan depresiasi capital intensity maupun keinginan untuk mempertahankan jumlah likuiditas yang dimiliki.

6. Dari kasus PT RNI yang mengubah pencatatan modal menjadi utang mengindikasikan bahwa masih terdapat perusahaan yang menggunakan utang yang menimbulkan beban bunga untuk mengurangi beban pajak yang terutang sehingga diidentifikasi bahwa utang/leverage menjadi alat bagi perusahaan melakukan agresivitas pajak. Dari kasus PT RNI, sebagai PMA yang memanfaatkan PP 46/2013 tentang Pajak Penghasilan khusus UMKM yang dinilai tidak etis menggambarkan bahwa masih terdapat perusahaan yang memanfaatkan ukuran perusahaan untuk melakukan agresivitas pajak.

\subsection{Tujuan dan Manfaat Penelitian}

Tujuan penelitian ini adalah untuk memperoleh bukti empiris mengenai pengaruh manajemen laba, proporsi komisaris independen, profitabilitas, capital intensity, dan likuiditas secara parsial maupun simultan bersama dengan variabel kontrol ukuran perusahaan dan leverage terhadap tax aggressiveness pada perusahaan manufaktur yang terdaftar di Bursa Efek Indonesia. Penelitian ini diharapkan dapat memberikan manfaat terutama bagi perusahaan dan pemerintah. Bagi perusahaan, perusahaan dapat memperoleh gambaran dan masukan mengenai pentingnya penerapan manajemen laba dan manajemen pajak yang tepat agar dapat menjadi perusahaan yang sehat terutama dalam hal pembayaran pajak secara jujur dan benar. Bagi pemerintah, dapat memberikan masukan dan menjadi bahan pertimbangan dalam memperbaharui maupun merumuskan kebijakan baru khususnya di bidang perpajakan.

\section{Kajian Pustaka}

\subsection{Teori Keagenan}

Teori keagenan adalah teori yang menyatakan adanya hubungan kontrak antara satu orang atau lebih (disebut dengan principal) dengan mempekerjakan pihak lain (disebut dengan agent) untuk melakukan jasa atas nama principal yang mencakup pendelegasian wewenang berupa otoritas pengambilan keputusan oleh agent (Jensen dan Meckling, 1976). Berdasarkan kontrak, principal mendelegasikan beberapa contoh otoritas pengambilan keputusan kepada agent. Baik pihak principal maupun pihak agent merupakan pemaksimal utilitas sehingga tidak ada alasan untuk mempercayai bahwa agent 
akan selalu bertindak sesuai dengan kepentingan principal (Godfrey et al., 2010, p362). Scholes et al. (2005) dalam Zemzem and Ftouhi (2013) mengungkapkan hakikat dan luasnya agency conflict dapat mempengaruhi level dari agresivitas pajak. Hal ini disebabkan adanya beberapa biaya dari agresivitas pajak yang tidak berkaitan dengan pajak seperti biaya yang muncul dari tindakan tersembunyi oleh manajer (Zemzem dan Ftouhi, 2013).

\subsection{Teori Akuntansi Positif}

Hipotesis dalam teori akuntansi positif yang dirumuskan oleh Watt \& Zimmerman (1986) dalam bentuk "oportunistik" yang sering diinterpretasikan (Indira, 2004):

1. Hipotesis rencana bonus (Plan Bonus Hypothesis), dalam ceteris paribus para manajer perusahaan dengan rencana bonus akan lebih memungkinkan untuk memilih prosedur akuntansi yang dapat menggantikan laporan earning untuk periode mendatang ke periode sekarang atau dikenal dengan income smoothing.

2. Hipotesis perjanjian utang (Debt Convenat Hypothesis), dalam ceteris paribus manajer perusahaan yang mempunyai rasio leverage (debt/equity) yang besar akan lebih suka memilih prosedur akuntansi yang dapat menggantikan laporan earning untuk periode mendatang ke periode sekarang.

3. Hipotesis biaya proses politik (Politic Process Hypothesis), dalam ceteris paribus semakin besar biaya politik perusahaan, semakin mungkin manajer perusahaan untuk memilih prosedur akuntansi yang menangguhkan laporan earning periode sekarang ke periode mendatang.

Ketiga hipotesis ini sering digunakan manajemen untuk menyajikan laba dalam laporan keuangan yang berdampak pada pajak penghasilan yang terutang. Hal ini dapat mengindikasikan agresivitas pajak yang dilakukan oleh perusahaan.

\subsection{Pajak Penghasilan}

Pajak Penghasilan $(\mathrm{PPh})$ adalah pajak yang dikenakan terhadap subjek pajak atas penghasilan yang diterima atau diperolehnya dalam suatu tahun pajak (Resmi, 2017, p70). Dasar Pengenaan Pajak (DPP) atas pajak penghasilan badan adalah Penghasilan Kena Pajak. Perhitungan laba fiskal berdasarkan mekanisme atau prinsip taxable dan deductible (taxabilitydeductibility mechanism) yang dilakukan dengan mengurangi penghasilan yang termasuk objek pajak sesuai Pasal 4 ayat (1) UU No. 36 Tahun 2008 dengan beban yang diperkenankan sebagai pengurang yang diatur dalam Pasal 6 ayat (1) UU No. 36 Tahun 2008. Implementasi dari konsep taxability deductibility juga berarti bahwa biaya-biaya baru dapat dikurangkan dari penghasilan bruto dari pihak pembayar apabila pihak penerima uang atas biaya perusahaan tersebut melaporkannya sebagai penghasilan dan penghasilan tersebut dikenai pajak (Pohan, 2015, p240-241). Perhitungan laba komersial mengacu pada konsep matching of cost with revenue (pengaitan biaya dengan pendapatan). Konsep ini melibatkan pengakuan penghasilan dan beban secara gabungan atau bersamaan yang dihasilkan secara langsung dan bersama-sama dari peristiwa lain yang sama. Apabila pengakuan suatu pendapatan ditunda, maka pembebanan biayanya juga akan ditunda sampai saat diakuinya pendapatan tersebut (Pohan, 2015, p241). Karena terjadi perbedaan dalam perhitungan laba akuntansi dan laba kena pajak, perusahaan dapat memilih perlakuan pajak yang tepat sehingga dapat menghasilkan efisiensi pajak yang besar.

\subsection{Agresivitas Pajak}

Agresivitas pajak menurut Frank et al. (2009) adalah tindakan manipulasi untuk mengurangi penghasilan kena pajak melalui perencanaan pajak yang dapat atau tidak dapat dipertimbangkan sebagai penghindaran pajak yang menyimpang (fraudulent tax evasion).

\subsection{Manajemen Laba}

Manajemen laba merupakan keputusan manajer untuk memilih kebijakan akuntansi tertentu atau dengan tindakan nyata yang dapat mempengaruhi earnings untuk menghasilkan tujuan pelaporan laba yang spesifik (Scott, 2012, p423). 


\subsection{Proporsi Komisaris Independen}

Komisaris independen didefinisikan sebagai seorang yang tidak terafiliasi dalam segala hal dengan shareholder, tidak memiliki hubungan dengan direksi atau dewan komisaris serta tidak menjabat sebagai direktur pada suatu perusahaan yang terkait dengan perusahaan pemilik (Kusuma dan Firmansyah, 2017).

\subsection{Profitabilitas}

Profitabilitas merupakan sumber utama yang menunjukkan kepastian kemampuan perusahaan untuk memenuhi pembayaran pokok dan bunga jangka panjangnya (Subramanyam, 2014, p9).

\subsection{Capital Intensity}

Rodriguez dan Arias (2014b) menyebutkan bahwa property, plant, and equipment yang dimiliki perusahaan memungkinkan perusahaan untuk memotong pajak akibat depresiasi dari property, plant, and equipment setiap tahunnya.

\subsection{Likuiditas}

Likuiditas adalah kemampuan perusahaan untuk menukarkan aset menjadi kas atau untuk mendapatkan uang tunai untuk memenuhi kewajiban jangka pendek (Subramanyam, 2014, p544).

\subsection{Ukuran Perusahaan}

Ukuran perusahaan adalah ukuran yang menunjukkan besar kecilnya suatu perusahaan, yang dapat dilihat dari nilai pasar saham, kapitalisasi pasar, total aset, dan lain-lain (Widjadja, 2009 dalam Hadi dan Mangonting, 2014)

\subsection{Leverage}

Leverage digunakan untuk menjelaskan penggunaan utang untuk membiayai sebagian dari aktiva korporasi. Pembiayaan dengan utang mempunyai pengaruh bagi korporasi karena utang mempunyai beban yang bersifat tetap (Tampubolon, 2013, p41)

\subsection{Pengembangan hipotesis}

Manajemen Laba dan Agresivitas Pajak

Salah satu motivasi manajer melakukan manajemen laba adalah motivasi pajak, bahwa perusahaan yang menginginkan penyajian laporan fiskal yang lebih rendah dari nilai yang sebenarnya memotivasi manajer untuk melakukan manajemen laba agar seolah-olah laba fiskal yang dilaporkan memang lebih rendah tanpa melanggar aturan dan kebijakan akuntansi perpajakan (Sulistiawan et al., 2011, p31-37).

$\mathrm{H}_{1}$ : Manajemen laba berpengaruh signifikan terhadap tax aggressiveness.

\section{Proporsi Komisaris Independen dan Agresivitas Pajak}

Zemzem dan Ftouhi (2013) menyatakan komisaris independen dapat meningkatkan kemampuan dewan untuk memantau manajemen secara efektif dalam situasi yang ditandai oleh masalah keagenan yang timbul dari pemisahan kepemilikan, pengendalian, dan dapat membantu mengurangi agresivitas pajak.

$\mathrm{H}_{2}$ : Proporsi komisaris independen berpengaruh signifikan terhadap tax aggressiveness.

\section{Profitabilitas dan Agresivitas Pajak}

Profitabilitas merupakan faktor penentu beban pajak karena perusahaan dengan laba yang lebih besar akan membayar pajak lebih besar pula dan sebaliknya. Bahkan, dengan restitusi atau kompensasi (carryback or carryforward) perusahaan dapat mengurangi kewajiban pajaknya untuk keuangan tahun sebelumnya maupun tahun berikutnya. Ini mewakili bentuk manfaat dari beban pajak atau perusahaan yang mengalami kerugian (Rodriguez dan Arias, 2014).

$\mathrm{H}_{3}$ : Profitabilitas berpengaruh signifikan terhadap tax aggressiveness.

\section{Capital Intensity dan Agresivitas Pajak}

Penelitian yang dilakukan oleh Jessica dan Toly (2014) menunjukkan bahwa capital intensity berpengaruh terhadap agresivitas pajak. Adanya hubungan antara capital intensity dengan agresivitas pajak karena akumulasi depresiasi yang disesuaikan 
dengan masa aset (Gupta dan Newberry, 1997 dalam Jessica dan Toly, 2014). Semakin besar capital intensity yang dimiliki perusahaan, peluang untuk mengurangi jumlah pajak semakin besar dengan membebankan depresiasi yang dapat menjadi pengurang penghasilan kena pajak.

$\mathrm{H}_{4}$ : Capital intensity berpengaruh signifikan terhadap tax aggressiveness.

\section{Likuiditas dan Agresivitas Pajak}

Menurut Suyanto dan Supramono (2012) likuiditas suatu perusahaan diprediksi akan mempengaruhi agresivitas pajak perusahaan karena perusahaan yang memiliki likuiditas tinggi menggambarkan memiliki arus kas yang baik sehingga perusahaan tersebut tidak enggan untuk membayar seluruh kewajibannya termasuk membayar pajak sesuai dengan aturan yang berlaku. Hal ini menunjukkan keuangan perusahaan dalam kondisi yang sehat dan tidak memiliki masalah mengenai arus kas sehingga mampu menanggung biaya-biaya yang muncul seperti pajak.

$\mathrm{H}_{5}$ : Likuiditas berpengaruh signifikan terhadap tax aggressiveness.

\section{Manajemen Laba, Proporsi Komisaris Independen, Profitabilitas, Capital Intensity, dan Likuiditas dengan variabel kontrol Ukuran Perusahaan dan Leverage terhadap Tax Aggressiveness}

Variabel-variabel yang telah diuraikan di atas merupakan unsur-unsur yang dimiliki dan dijadikan alat oleh perusahaan sehingga dalam kondisi bersama-sama diprediksi akan memiliki pengaruh terhadap agresivitas pajak perusahaan.

$\mathrm{H}_{6}$ : Manajemen laba, proporsi komisaris independen, profitabilitas, capital intensity, dan likuiditas dengan variabel kontrol ukuran perusahaan dan leverage secara simultan berpengaruh signifikan terhadap tax aggressiveness.

\section{Metode Penelitian \\ 3.1 Rancangan Penelitian dan Model Penelitian}

Penelitian ini bersifat kuantitatif dengan menggunakan data rasio. Bentuk penelitian ini adalah kausalitas. Penelitian kausalitas bertujuan untuk menguji apakah suatu variabel menyebabkan perubahan terhadap variabel yang lain. Dengan kata lain, tujuan peneliti adalah melakukan penelitian kausal yang dapat menyatakan bahwa variabel $\mathrm{X}$ berpengaruh terhadap variabel Y (Sekaran dan Bougie, 2013, p98).

Data yang digunakan dalam penelitian ini adalah data sekunder yang diperoleh dari website resmi BEI (www.idx.co.id). Subjek penelitian ini adalah perusahaan manufaktur yang terdaftar di BEI. Metode pemilihan sampel yang digunakan adalah nonprobability sampling tipe purposive sampling dengan kriteria sebagai berikut.

1. Perusahaan manufaktur yang terdaftar secara konsisten di BEI selama tahun 2012-2016.

2. Perusahaan manufaktur yang menyajikan laporan keuangan dalam mata uang Rupiah selama tahun 20122016.

3. Perusahaan manufaktur yang memiliki tahun buku yang berakhir pada 31 Desember selama tahun 2012-2016.

4. Perusahaan manufaktur yang tidak memiliki zero (0) profit atau negative income selama tahun 2012-2016.

5. Perusahaan manufaktur yang tidak memiliki nilai ETR $<0$ atau $>1$.

Model penelitian dalam penelitian ini dirumuskan sebagai berikut.

$Y=\alpha+\beta_{1} X_{1}+\beta_{2} X_{2}+\beta_{3} X_{3}+\beta_{4} X_{4}+\beta_{5} X_{5}$ $+\beta_{6} X_{6}+\beta_{7} X_{7}+\varepsilon$

\subsection{Pengukuran Operasional Variabel}

Pengukuran operasional variabel dirangkum dalam tabel 1 berikut: 
Tabel 1

Operasionalisasi Variabel

\begin{tabular}{|c|c|c|c|}
\hline \multicolumn{2}{|c|}{ Variabel } & Pengukuran & Skala \\
\hline \multirow[b]{2}{*}{ Dependen } & $\operatorname{Tax}$ & & Rasio \\
\hline & Aggressivenes & Total Tax Expense & \\
\hline & $\begin{array}{l}\text { Manajemen } \\
\text { Laba }\end{array}$ & $\begin{array}{c}\mathrm{DACC}_{\mathrm{it}}=\mathrm{TACC}_{\mathrm{it}} / \mathrm{A}_{\mathrm{it}-1}-\mathrm{NDA}_{\mathrm{it}} \\
(\text { Novitasari, 2017) }\end{array}$ & Rasio \\
\hline Independen & $\begin{array}{l}\text { Proporsi } \\
\text { Komisaris } \\
\text { Independen }\end{array}$ & PKI $=\frac{\text { Jumlah Komisaris Independen }}{\text { Total Dewan Komisaris }}$ & Rasio \\
\hline
\end{tabular}

(Tiaras dan Wijaya, 2015)

$\begin{array}{lll} & \text { (Tiaras dan Wijaya, 2015) } \\ \text { POA }=\frac{\text { Operating Income }}{\text { Total Assets }} & \text { Rasio }\end{array}$

\begin{tabular}{lcc}
$\begin{array}{l}\text { Capital } \\
\text { Intensity }\end{array}$ & CINT $=\frac{\text { Total Aset Tetap Bersih }}{\text { Total Aset }}$ & Rasio \\
& (Jessica dan Toly, 2014) & \\
\hline Likuiditas & $\mathrm{LIQ}=\frac{\text { Aset Lancar }}{\text { Kewajiban Lancar }}$ & Rasio
\end{tabular}

(Tiaras dan Wijaya, 2015)

\begin{tabular}{llcc}
\hline \multirow{2}{*}{ Kontrol } & $\begin{array}{l}\text { Ukuran } \\
\text { perusahaan }\end{array}$ & $\begin{array}{c}\text { Size }=\text { Ln total aset } \\
(\text { Tiaras dan Wijaya, 2015) }\end{array}$ & Rasio \\
\cline { 2 - 4 } & Leverage & LEV= Total Utang & Rasio \\
& &
\end{tabular}

(Tiaras dan Wijaya, 2015)

\subsection{Metode Analisis Data}

Metode analisis data terdiri dari statistik deskriptif, uji asumsi klasik, dan uji hipotesis dengan menggunakan analisis regresi berganda. Alat statistik yang digunakan adalah IBM SPSS versi 23 .

\section{HASIL DAN PEMBAHASAN 4.1. Penyajian Data}

Berdasarkan kriteria pemilihan sampel, dihasilkan 51 sampel selama lima tahun pengamatan dan diperoleh total 255 data yang dapat dilihat pada tabel 2 berikut.

Tabel 2

Pemilihan Sampel

\begin{tabular}{clcc}
\hline No. & \multicolumn{1}{c}{ Kriteria } & $\begin{array}{c}\text { Jumlah } \\
\text { Perusahaan }\end{array}$ & $\begin{array}{c}\text { Jumlah } \\
\text { Data }\end{array}$ \\
\hline 1. & $\begin{array}{l}\text { Perusahaan manufaktur } \\
\text { Perusahaan manufaktur yang delisting di BEI selama tahun 2012- }\end{array}$ & 144 & 720 \\
2016. & & $(85)$ \\
3. & $\begin{array}{l}\text { Perusahaan manufaktur yang tidak menyajikan laporan keuangan } \\
\text { dalam mata uang Rupiah selama tahun 2012- 2016. }\end{array}$ & $(27)$ & $(135)$ \\
4. & $\begin{array}{l}\text { Perusahaan manufaktur yang tidak memiliki tahun buku yang berakhir } \\
\text { pada 31 Desember selama tahun 2012-2016. }\end{array}$ & 0 & 0 \\
5. & $\begin{array}{l}\text { Perusahaan manufaktur yang memiliki zero }(0) \text { profit atau negative } \\
\text { income selama tahun 2012- 2016. }\end{array}$ & $(46)$ & $(230)$ \\
6. & Perusahaan manufaktur yang memiliki nilai ETR $<0$ atau $>1$ & $(3)$ & $(15)$ \\
\hline & Total sampel terpilih & 51 & 255 \\
\hline
\end{tabular}

Sumber: data sekunder yang diolah, 2017 


\subsection{Statistik Deskriptif}

Hasil pengolahan statistik deskriptif dalam penelitian ini terhadap setiap variabel, baik variabel dependen maupun variabel independen tercermin dalam tabel 3 berikut

Tabel 3

Hasil Statistik Deskriptif s

\begin{tabular}{|c|c|c|c|c|c|}
\hline & $\mathrm{N}$ & Minimum & Maximum & Mean & Std. Deviation \\
\hline ETR & 255 & 0663 & ,7099 & ,261398 & ,0751678 \\
\hline DA & 255 &,- 1179 & ,4369 &, 134354 & ,0887915 \\
\hline PKI & 255 & ,2000 & ,8000 &, 400058 & ,1089882 \\
\hline ROA & 255 & ,0016 & (5396 & ,136161 & ,1068206 \\
\hline CINT & 255 & ,07020 & ,78400 & ,3302314 & , 15060337 \\
\hline LIQ & 255 & ,6056 & 9,3446 & 2,437457 & 1,4681495 \\
\hline SIZE & 255 & 25,5796 & 33,1988 & 28,417548 & 1,6610176 \\
\hline LEV & 255 &, 1306 & ,8809 & ,411989 & ,1709101 \\
\hline Valid N (listwise) & 255 & & & & \\
\hline
\end{tabular}

Sumber: Pengolahan Data dengan IBM SPSS 23

Variabel Tax Aggressiveness (TAG) yang diproksikan dengan ETR menunjukkan nilai minimum 0,0663 , nilai maksimum 0,7099 , nilai rata-rata 0,261398 dan standar deviasi 0,0751678. Hal ini berarti beban pajak rata-rata perusahaan manufaktur sebesar $26,14 \%$ dari pretax income.

Variabel manajemen laba (DA) menunjukkan nilai minimum $-0,1179$, nilai maksimum 0,4369 , nilai rata-rata 0,134354 dan standar deviasi 0,0887915. Hal ini menunjukkan bahwa rata-rata perusahaan manufaktur secara umum melakukan manajemen laba dengan melakukan kebijakan akrual yang menaikkan laba sebesar $13,44 \%$ dari total aset $\mathrm{t}-1$ namun juga terdapat perusahaan manufaktur yang menurunkan laba sebesar $-11,79 \%$ dari total aset $\mathrm{t}-1$.
Variabel proporsi komisaris independen (PKI) menunjukkan nilai minimum 0,2000, nilai maksimum 0,8000 , nilai rata-rata 0,400058 dan standar deviasi 0,1089882 . Hal ini berarti bahwa rata-rata perusahaan manufaktur telah memenuhi syarat minimum $30 \%$ keberadaan komisaris independen dalam perusahaan.

\subsection{Uji Asumsi Klasik}

a. Uji Normalitas

Hasil uji normalitas dengan uji statistik non-parametrik K-S pada tabel 4 di atas menunjukkan nilai Asymp. Sig. (2tailed) sebesar 0,062 > 0,05 maka $\mathrm{H} 0$ diterima dan Ha ditolak, artinya data residual berdistribusi normal dan memenuhi syarat dalam pengujian regresi

Tabel 4

Hasil Uji Normalitas

One-Sample Kolmogorov-Smirnov Test

\begin{tabular}{llr}
\hline & & Unstandardized Residual \\
\hline $\mathrm{N}$ & & 255 \\
\hline Normal Parameters ${ }^{\mathrm{a}, \mathrm{b}}$ & Mean &, 0000000 \\
& Std. Deviation &, 07699483 \\
\hline Most Extreme & Absolute &, 055 \\
Differences & Positive &, 055 \\
& Negative &,- 035 \\
\hline Test Statistic & &, 055 \\
\hline Asymp. Sig. (2-tailed) & &, $062^{\mathrm{c}}$ \\
\hline a. Test distribution is Normal. & \\
b. Calculated from data. & & \\
c. Lilliefors Significance Correction. &
\end{tabular}

Sumber: Hasil pengolahan data dengan SPSS IBM 23. 
b. Uji Multikolonieritas

Hasil uji multikolinieritas pada tabel 5 di atas menunjukkan bahwa variabel manajemen laba, proporsi komisaris independen, profitabilitas, capital intensity, dan likuiditas dengan variabel kontrol ukuran perusahaan dan leverage menghasilkan nilai tolerance $>0,1$ dan nilai VIF < 10 maka dapat disimpulkan setiap variabel tidak terjadi multikolinieritas. Secara keseluruhan dapat disimpulkan bahwa Ha ditolak dan H0 diterima yang berarti bahwa tidak terjadi multikolinieritas antar variabel independen sehingga model regresi baik digunakan dalam penelitian ini.

c. Uji Autokorelasi
Tabel 5

Hasil Uji Multikolinieritas

\begin{tabular}{|c|c|c|c|}
\hline \multirow{2}{*}{\multicolumn{2}{|c|}{ Model }} & \multicolumn{2}{|c|}{ Collinearity Statistics } \\
\hline & & Tolerance & VIF \\
\hline \multirow[t]{8}{*}{1} & (Constant) & & \\
\hline & DA & ,832 & 1,202 \\
\hline & PKI & ,782 & 1,279 \\
\hline & ROA & 689 & 1,452 \\
\hline & CINT & 695 & 1,440 \\
\hline & LIQ & 350 & 2,855 \\
\hline & SIZE & ,933 & 1,072 \\
\hline & LEV & 375 & 2,665 \\
\hline
\end{tabular}

a. Dependent Variable: ETR

Sumber: Hasil pengolahan data dengan SPSS IBM 23

Tabel 6

Hasil Uji Autokorelasi

Coefficients

\begin{tabular}{|c|c|c|c|c|c|c|}
\hline \multicolumn{2}{|c|}{ Model } & \multicolumn{2}{|c|}{ Unstandardized Coefficients } & \multirow{2}{*}{$\begin{array}{l}\text { Standardized } \\
\text { Coefficients } \\
\text { Beta }\end{array}$} & \multirow[t]{2}{*}{$\mathrm{T}$} & \multirow[t]{2}{*}{ Sig. } \\
\hline & & B & Std. Error & & & \\
\hline \multirow[t]{9}{*}{1} & (Constant) &,- 005 &, 085 & &,- 057 & 955 \\
\hline & DA & ,001 & ,053 & ,001 &, 010 & 992 \\
\hline & PKI &, 000 & 044 &,- 001 &,- 011 & ,991 \\
\hline & ROA &,- 001 & 048 &,- 002 &,- 023 & ,981 \\
\hline & CINT &,- 002 & 034 &,- 003 &,- 045 & 964 \\
\hline & LIQ & $3,758 \mathrm{E}-5$ & ,005 & ,001 & ,008 & 994 \\
\hline & SIZE &, 000 & 003 & ,004 &, 068 & ,946 \\
\hline & LEV & ,001 & 041 & 002 & 023 & 982 \\
\hline & RES_2 &, 027 &, 064 & ,027 & 425 & 671 \\
\hline
\end{tabular}

Dari tabel 6 dapat diketahui bahwa nilai RES_2 menghasilkan tingkat signifikansi $\alpha$ sebesar $0,671>0,05$ maka H0 diterima dan Ha ditolak sehingga dapat disimpulkan bahwa model regresi tidak terjadi autokorelasi.

\section{d. Uji Heteroskedastisitas}

Dari tabel 7 dapat diketahui bahwa variabel manajemen laba, proporsi komisaris independen, profitabilitas, capital intensity, dan likuiditas dengan variabel kontrol ukuran perusahaan dan leverage menghasilkan tingkat signifikansi $\alpha>0,05$. Oleh karena itu, dapat disimpulkan Ha ditolak dan $\mathrm{HO}$ yang menyatakan bahwa model regresi tidak terdapat heteroskedastisitas diterima.

Tabel 7

Hasil Uji Heteroskedastisitas ${ }^{\text {a }}$

\begin{tabular}{|c|c|c|c|}
\hline \multirow[t]{2}{*}{ Model } & Unstandardized Coefficients & $\begin{array}{l}\text { Standardized } \\
\text { Coefficients }\end{array}$ & \multirow[t]{2}{*}{ Sig. } \\
\hline & Std. Error & Beta & \\
\hline
\end{tabular}




\begin{tabular}{rlrrrrr}
\hline 1 & (Constant) & $-1,940$ & 2,501 & &,- 776 &, 440 \\
& DA &, 392 & 1,824 &, 023 &, 215 &, 830 \\
& PKI &, 963 & 1,368 &, 085 &, 704 &, 483 \\
& ROA & $-1,402$ & 1,200 &,- 136 & $-1,168$ &, 245 \\
& CINT &,- 971 & 1,148 &,- 103 &,- 846 &, 400 \\
& LIQ &, 234 &, 166 &, 242 & 1,415 &, 160 \\
& SIZE &,- 106 &, 080 &,- 130 & $-1,329$ &, 186 \\
& LEV & 2,053 & 1,329 &, 254 & 1,544 &, 125 \\
\hline
\end{tabular}

Sumber: Hasil pengolahan data dengan SPSS IBM 23

\subsection{Analisis Regresi Berganda}

Tabel 8

Hasil Analisis Regresi Linier Berganda

\begin{tabular}{|c|c|c|c|c|c|c|}
\hline \multicolumn{2}{|c|}{ Model } & \multicolumn{2}{|c|}{ Unstandardized Coefficients } & \multirow{2}{*}{$\begin{array}{c}\begin{array}{c}\text { Standardized } \\
\text { Coefficients }\end{array} \\
\text { Beta }\end{array}$} & \multirow[t]{2}{*}{$\mathrm{t}$} & \multirow[t]{2}{*}{ Sig. } \\
\hline & & B & Std. Error & & & \\
\hline \multirow[t]{8}{*}{1} & (Constant) & ,468 & ,084 & & 5,600 & ,000 \\
\hline & DA &,- 181 & ,053 &,- 215 & $-3,445$ & , 001 \\
\hline & PKI & ,038 & ,044 & ,056 & ,864 & ,388 \\
\hline & ROA &,- 180 & ,048 &,- 256 & $-3,741$ & ,000 \\
\hline & CINT & ,064 & ,034 & ,129 & 1,894 & ,059 \\
\hline & LIQ & ,008 & ,005 & , 159 & 1,658 & , 099 \\
\hline & SIZE &,- 009 & ,003 & -,208 & $-3,529$ & , 000 \\
\hline & LEV & ,126 & ,041 & ,288 & 3,100 & ,002 \\
\hline
\end{tabular}

a. Dependent Variable: ETR

Sumber: Hasil pengolahan data dengan SPSS IBM 23

Berdasarkan tabel 8 maka persamaan regresi yang terbentuk sebagai berikut.

$$
\begin{aligned}
\text { ETR }= & 0,468-0,181 \text { DA + 0,038 PKI }- \\
& 0,180 \text { ROA + 0,064 CINT + 0,008 } \\
& \text { LIQ - 0,009 SIZE + 0,126 LEV + } \\
& \varepsilon
\end{aligned}
$$

Keterangan:

ETR : Effective Tax Rate yang

Mengindikasikan tingkat

agresivitas pajak

DA : Manajemen Laba

PKI : Proporsi Komisaris Independen

ROA : Return of Asset sebagai proksi

Profitabilitas

CINT : Capital Intensity

LIQ : Likuiditas

SIZE : Ukuran perusahaan

sedangkan sisanya sebesar $82,2 \%$ dijelaskan oleh variabel lain di luar model regresi atau model penelitian ini.

\section{LEV : Leverage \\ $\varepsilon \quad:$ Standard Error}

\section{a. Uji Koefisien Determinasi}

Nilai adjusted $\mathrm{R}^{2}$ pada tabel 4.9 adalah sebesar 0,178 atau $17,8 \%$. Nilai tersebut mengartikan bahwa secara statistik besarnya variasi variabel dependen tax aggressiveness dapat dijelaskan oleh variabel independen manajemen laba, proporsi komisaris independen, profitabilitas, capital intensity, dan likuiditas dengan variabel kontrol ukuran perusahaan dan leverage sebesar 17,8\%

Tabel 9

Hasil Uji Koefisien Determinasi

Model Summary ${ }^{\mathrm{b}}$

\begin{tabular}{ccccr}
\hline Model & R & R Square & Adjusted R Square & Std. Error of the Estimate \\
\hline 1 &, $448^{\text {a }}$ &, 201 &, 178 &, 06800 \\
\hline
\end{tabular}

a. Predictors: (Constant), LEV, DA, SIZE, PKI, CINT, ROA, LIQ

b. Dependent Variable: ETR 
b. Uji t

\begin{tabular}{|c|c|c|c|c|c|c|}
\hline \multicolumn{7}{|c|}{$\begin{array}{c}\text { Tabel 10 } \\
\text { Hasil Uji t } \\
\text { Coefficients }^{\mathrm{a}}\end{array}$} \\
\hline \multirow{2}{*}{\multicolumn{2}{|c|}{ Model }} & \multicolumn{2}{|c|}{ Unstandardized Coefficients } & \multirow{2}{*}{$\begin{array}{c}\text { Standardized Coefficients } \\
\text { Beta } \\
\end{array}$} & \multirow[t]{2}{*}{$\mathrm{T}$} & \multirow[t]{2}{*}{ Sig. } \\
\hline & & $\mathrm{B}$ & Std. Error & & & \\
\hline 1 & (Constant) & ,468 &, 084 & & 5,600 & ,000 \\
\hline & DA &,- 181 & 053 &,- 215 & $-3,445$ & 001 \\
\hline & PKI &, 038 & 044 &, 056 & ,864 & ,388 \\
\hline & ROA &,- 180 & ,048 &,- 256 & $-3,741$ &, 000 \\
\hline & CINT &, 064 & 034 &, 129 & 1,894 & 059 \\
\hline & LIQ & 008 & 005 &, 159 & 1,658 & ,099 \\
\hline & SIZE &,- 009 & 003 &,- 208 & $-3,529$ & 000 \\
\hline & LEV &, 126 & 041 &, 288 & 3,100 &, 002 \\
\hline
\end{tabular}

a. Dependent Variable: ETR

Sumber: Hasil pengolahan data dengan SPSS IBM 23

Hasil pengujian pada tabel 10 Manajemen laba (DA) menghasilkan koefisien regresi sebesar $-3,445$. Nilai signifikansi $\alpha$ sebesar 0,001 berada di bawah tingkat signifikansi $\alpha=0,05$ menunjukkan bahwa manajemen laba berpengaruh signifikan terhadap ETR sehingga $\mathrm{H}_{1}$ diterima. Koefisien regresi bertanda negatif menunjukkan bahwa semakin tinggi manajemen laba yang dilakukan perusahaan maka semakin rendah nilai ETR yang menunjukkan tingkat agresivitas pajak perusahaan yang tinggi. Berdasarkan teori keagenan, adanya asimetris informasi dan benturan kepentingan membuat manajer berusaha melakukan manajemen laba untuk kepentingan pribadi, perusahaan, dan khususnya pada pihak regulator dengan memberikan informasi melalui pelaporan penghasilan kena pajak yang telah dimodifikasi agar beban pajak yang dibayar sesuai dengan kepentingan perusahaan. Manajemen laba dilakukan dalam bentuk income decreasing untuk menurunkan laba sebelum pajak agar jumlah beban pajak menjadi rendah.

Proporsi komisaris independen menghasilkan koefisien regresi sebesar 0,864 . Tanda positif pada koefisien regresi mengartikan bahwa semakin besar proporsi komisaris independen maka nilai ETR yang dihasilkan semakin tinggi yang menunjukkan rendahnya tingkat agresivitas pajak yang dilakukan oleh perusahaan. Namun, nilai signifikansi $\alpha$ sebesar 0,388 berada di atas tingkat signifikansi $\alpha=0,05$ menunjukkan bahwa proporsi komisaris independen tidak berpengaruh signifikan terhadap ETR sehingga $\mathrm{H}_{2}$ ditolak. Dalam pasal 108 ayat (1) UU No. 40 tentang Perseroan Terbatas disebutkan bahwa dewan komisaris melakukan pengawasan atas kebijakan pengurusan, jalannya pengurusan pada umumnya, baik mengenai perseroan maupun usaha perseroan, dan memberi nasihat kepada direksi. Hal ini menunjukkan bahwa komisaris independen lebih berfokus pada pengawasan pada umumnya, yaitu review bersama direksi untuk menetapkan kebijakan di tahun mendatang, pengambilan keputusan untuk memberikan persetujuan atau bantuan kepada direksi dalam melakukan perbuatan hukum tertentu seperti kebijakan mengenai merger atau akuisisi yang akan dilakukan perusahaan dan lebih menitikberatkan pada hal-hal penting bagi perusahaan daripada jalannya operasional seharihari termasuk di antaranya besaran jumlah pajak yang dibayar.

Profitabilitas (ROA) menghasilkan koefisien regresi sebesar $-3,741$. Nilai signifikansi $\alpha 0,000$ di bawah tingkat signifikansi $\alpha=0,05$ membuktikan bahwa $\mathrm{H}_{3}$ diterima. Koefisien regresi bertanda negatif menunjukkan bahwa semakin tinggi profitabilitas 
perusahaan maka semakin rendah nilai ETR. Semakin rendah nilai ETR menunjukkan tingkat agresivitas pajak perusahaan yang tinggi. Berdasarkan hipotesis biaya proses politik dalam teori akuntansi positif, perusahaan dengan tingkat profitabilitas yang tinggi memiliki kemampuan untuk mengelola sumber daya melalui pemilihan prosedur akuntansi yang mendukung dalam mengefisienkan beban pajak yang harus dibayar. Selain itu, perusahaan dengan tingkat profitabilitas yang tinggi memiliki peluang untuk memanfaatkan insentif pajak secara agresif sehingga beban pajak yang terutang dapat menjadi lebih kecil dari yang seharusnya.

Capital intensity memiliki nilai koefisien regresi sebesar 1,894. Tanda positif koefisien capital intensity menunjukkan bahwa semakin besar capital intensity yang dimiliki perusahaan maka nilai ETR semakin tinggi yang mencerminkan rendahnya tingkat agresivitas perusahaan. Namun, nilai signifikansi 0,059 yang berada di atas tingkat signifikansi $\alpha=0,05$ membuktikan bahwa $\mathrm{H}_{4}$ ditolak. Perusahaan manufaktur sebagai perusahaan yang mengolah bahan baku menjadi bahan jadi membutuhkan capital intensity berupa aset tetap dalam bentuk mesin-mesin dan truk. Capital intensity yang dimiliki oleh perusahaan diperoleh dan digunakan untuk menunjang kegiatan operasional dalam rangka mencapai tujuan utama perusahaan, yaitu menghasilkan produk untuk dijual. Perusahaan tidak akan mengambil risiko dengan membeli mesin dalam jumlah yang besar hanya untuk kepentingan mengurangi beban pajak. Perusahaan lebih memprioritaskan aset tetap yang dimiliki untuk mendukung keberlangsungan hidup.

Likuiditas menghasilkan koefisien regresi sebesar 1,658. Tanda positif pada koefisien likuiditas membuktikan bahwa semakin tinggi tingkat likuiditas perusahaan maka semakin tinggi pula ETR yang mengindikasikan agresivitas pajak perusahaan yang rendah. Namun, nilai signifikansi $\alpha$ sebesar 0,099 berada di atas tingkat signifikansi $\alpha=0,05$ menunjukkan bahwa likuiditas tidak berpengaruh terhadap ETR sehingga $\mathrm{H}_{5}$ ditolak. Current ratio yang tinggi akan menghambat perusahaan dalam memperoleh laba karena dana yang bersifat likuid cenderung tinggi dan diam di tempat. Dana yang likuid dan kurang efektif dalam operasional ini menghambat perolehan laba oleh perusahaan. Hal ini berdampak pada tidak berpengaruhnya likuiditas perusahaan terhadap ETR sehingga tidak berpengaruh terhadap agresivitas pajak perusahaan. Selain itu, beban pajak dikenakan atas penghasilan yang diperoleh atau diterima perusahaan bukan dari dana likuid yang bersifat diam yang dimiliki perusahaan.

\section{c. Uji F}

Tabel 11

ANOVA $^{\mathrm{a}}$

\begin{tabular}{|c|c|c|c|c|c|c|}
\hline \multicolumn{2}{|c|}{ Model } & $\begin{array}{l}\text { Sum of } \\
\text { Squares }\end{array}$ & $\mathrm{df}$ & $\begin{array}{c}\text { Mean } \\
\text { Square }\end{array}$ & $\mathrm{F}$ & Sig. \\
\hline \multirow[t]{3}{*}{1} & Regression & ,287 & 7 &, 041 & 8,857 &, $000^{\mathrm{b}}$ \\
\hline & Residual & 1,142 & 247 &, 005 & & \\
\hline & Total & 1,429 & 254 & & & \\
\hline
\end{tabular}

a. Dependent Variable: ETR

b. Predictors: (Constant), DA, PKI, CINT, ROA, LIQ, SIZE, LEV 
Hasil uji $F$ pada tabel 11 menunjukkan bahwa nilai signifikansi $\alpha$ sebesar 0,000 berada di bawah $\alpha=0,05$ maka hipotesis keenam $\left(\mathrm{H}_{6}\right)$ yang menyatakan bahwa variabel independen manajemen laba, proporsi komisaris independen, profitabilitas, capital intensity, likuiditas dengan variabel kontrol ukuran perusahaan dan leverage secara simultan berpengaruh signifikan terhadap variabel dependen $\operatorname{tax}$ aggressiveness diterima. Nilai signifikansi $\alpha 0,000<\alpha=0,05$ juga menunjukkan bahwa model fit dan layak digunakan dalam penelitian ini.

\section{Simpulan Dan Saran}

Berdasarkan hasil analisis data dan Simpulan yang dapat ditarik dari hasil penelitian ini sebagai berikut.

1. Manajemen laba secara parsial berpengaruh signifikan terhadap tax aggressiveness. Hasil penelitian ini sejalan dengan penelitian yang dilakukan oleh Kusuma dan Firmansyah (2017), Novitasari (2017), Tiaras dan Wijaya (2015), serta Suyanto dan Supramono (2012) namun tidak sejalan dengan penelitian yang dilakukan oleh Amril et al. (2015).

2. Proporsi komisaris independen secara parsial tidak berpengaruh signifikan terhadap tax aggressiveness. Hasil penelitian ini sejalan dengan penelitian yang dilakukan oleh Hadi dan Mangonting (2014) namun tidak sejalan dengan penelitian yang dilakukan oleh Tiaras dan Wijaya (2015) serta Suyanto dan Supramono (2012).

3. Profitabilitas secara parsial berpengaruh signifikan terhadap tax aggressiveness. Hasil penelitian ini sejalan dengan penelitian yang dilakukan oleh Rodriguez dan Arias (2014) serta Zemzem dan Ftouhi (2013) namun tidak sejalan dengan penelitian yang dilakukan oleh Boussaidi dan Hamed (2015), Jessica dan Toly (2014), Hadi dan Mangonting (2014), serta Hartadinata dan Tjaraka (2013).

4. Capital intensity secara parsial tidak berpengaruh signifikan terhadap tax aggressiveness. Hasil penelitian ini sejalan dengan penelitian yang dilakukan oleh Novitasari (2017) serta Hartadinata dan Tjakara (2013) namun tidak sejalan dengan penelitian yang dilakukan oleh Jessica dan Toly (2014).

5. Likuiditas secara parsial tidak berpengaruh signifikan terhadap tax aggressiveness. Hasil penelitian ini sejalan dengan penelitian yang dilakukan oleh Bradley (1994) dan Siahaan (2005) dalam Suyanto dan Supramono (2012) namun tidak sejalan dengan penelitian yang dilakukan oleh Suyanto dan Supramono (2012).

6. Variabel independen manajemen laba, proporsi komisaris independen, profitabilitas, capital intensity, dan likuiditas dengan variabel kontrol ukuran perusahaan dan leverage secara simultan berpengaruh signifikan terhadap variabel dependen $\operatorname{tax}$ aggressiveness.

Saran yang dapat diberikan untuk meningkatkan kualitas bagi penelitian selanjutnya, yaitu.

1. Peneliti selanjutnya dapat mengambil sektor lain sebagai sampel selain sektor manufaktur.

2. Peneliti selanjutnya dapat menggunakan pengukuran lain untuk agresivitas pajak, seperti book tax differences atau current ETR .

3. Peneliti selanjutnya dapat menambah variabel lain yang dapat mempengaruhi agresivitas pajak seperti tingkat inflasi, indeks harga konsumen, pajak tangguhan.

4. Peneliti selanjutnya dapat menambah variabel moderasi agar dapat diperoleh hasil yang lebih menggambarkan faktor-faktor yang mempengaruhi tax aggressiveness.

\section{Daftar Pustaka}

Agoes, S., \& Trisnawati, E. (2013). Akuntansi Perpajakan. Edisi 3. Jakarta: Salemba Empat. 
Amril, A., Puspa, D. F., \& Fauziati, P. (2015). Pengaruh Manajemen Laba dan Corporate Governance Terhadap Agresivitas Pajak Perusahaan Manufaktur yang Listing di Bursa Efek Indonesia. Jurnal Universitas Bung Hatta, Vol. 7, No.1.

Boussaidi, A., \& Mounira Sidhom Hamed. (2015). The Impact of Governance Mechanisms on Tax aggressiveness : Empirical Evidence from Tunisian Context. Asian Economic and Social Society, Vol. 5, No. 1.

Chen, S., Chen, X., Cheng, Q., \& Shevlin, T. (2010). Are Family Firms More Tax Aggressive Than Non-family Firms? Journal of Financial Economics, 95: 41-61.

Direktorat Jenderal Pajak Kementerian Keuangan. (2016). Refleksi Tingkat Kepatuhan Wajib Pajak. Dipetik Mei 12, 2017, dari http://www.pajak.go.id/content/articl e/refleksi-tingkat-kepatuhan-wajibpajak

Frank, M. M., Lynch, L. J., \& Rego, S. O. (2009). Tax Reporting Aggressiveness and Its Relation to Aggressive Financial Reporting. The Accounting Review, Vol. 84, No. 2, 467-496.

Ghozali, I. (2016). Aplikasi Analisis Multivariate Dengan Program SPSS IBM 23. Edisi Kedelapan. Semarang: Universitas Diponegoro.

Godfrey, J., Hodgson, A., Tarca, A., Hamilton, J., \& Holmes, S. (2010). Accounting Theory. Seventh edition. United State: John Wiley \& Sons, Inc.

Hadi, J., \& Mangonting, Y. (2014). Pengaruh Struktur Kepemilikan Dan Karakteristik Dewan Terhadap Agresivitas Pajak. Tax \& Accounting Review, Vol. 4, No. 2, 1-10.

Hartadinata, O. S., \& Tjakara, H. (2013). Analisis Pengaruh Kepemilikan Manajerial Kebijakan Utang Dan Ukuran Perusahaan Terhadap Tax Aggressiveness Pada Perusahaan Manufaktur Di Bursa Efek Indonesia Periode Tahun 2008-2010. Jurnal
Ekonomi dan Bisnis Airlangga, Vol. 23 No. 3.

Indira, J. (2004). Pendekatan dan Kritik Teori Akuntansi Positif. Jurnal Akuntani \& Auditing, Vol.1 No.1 November.

Jensen, M. C., \& Meckling, W. H. (1976). Theory of the Firm: Managerial Behaviour, Agency Cost, and Ownership Structure. Journal of Financial Economics, Vol. 3, 305360.

Jessica, \& Toly, A. A. (2014). Pengaruh Pengungkapan Corporate Sosial Responsibility Terhadap Agresivitas Pajak. Tax \& Accounting Review, Vol. 4, No. 1.

usuma, C. A., \& Firmansyah, A. (2017). Analisis Pengaruh Manajemen Laba, Corporate Governance Dan Kualitas Auditor Eksternal Terhadap Tax Aggressiveness. Universitas Pancasila Fakultas Ekonomi dan Bisnis. Jakarta: ISBN 978-60270083-4-2.

Minnick, K., \& Noga, T. (2010). Do Corporate Governance Characteristics Influence Tax Management? Journal of Corporate Finance 16 (2010), 703-718.

Mladineo, L., \& Susak, T. (2016). Determinants of Effective Tax Rate. 16th International Scientific Conference on Economic and Social Development - The Legal Challenges of Modern World.

Muttaqin, Z. (2015, Juni 24). www.kompasiana.com. Dipetik Januari 18, 2018, dari https://www.kompasiana.com/zenmuttaqin/4000-perusahaan-tak-bayarpajak-selama-7tahun_552c16f76ea834744a8b459a

Novitasari, S. (2017). Pengaruh Manajemen Laba, Corporate Governance, Dan Intensitas Modal Terhadap Agresivitas Pajak Perusahaan. JOM Fekon, Vol. 4 No.1 (Februari).

Peraturan Menteri Keuangan Republik Indonesia Nomor 169/PMK. 010/2015 Tentang Penentuan Besarnya Perbandingan antara Utang dan Modal Perusahaan Untuk 
Keperluan Penghitungan Pajak Penghasilan.

Pohan, C. (2015). Manajemen Perpajakan. Strategi Perencanaan Pajak Dan Bisnis. Edisi Revisi. Jakarta: PT Gramedia.

Ratmono, D., \& Sagala, W. M. (2015). Pengungkapan Corporate Social Responsibility (CSR) Sebagai Sarana Legitimasi: Dampaknya Terhadap Tingkat Agresivitas Pajak. Jurnal Nominal / Volume Iv Nomor 2 / Tahun 2015.

Resmi, S. (2017). Perpajakan Teori dan Kasus. Jakarta: Salemba Empat.

Richardson, G., \& Lanis, R. (2007). Determinants of The Variability in Corporate Effective Tax Rates and Tax. Journal of Accounting and Public Policy, 26 (2007), 689-704.

Rodriguez, E. F., \& Arias, A. M. (2014). Determinants of The Effective Tax Rate in BRIC Countries. Emerging Market Finance and Trade, Vol. 50, Supplement 3, pp. 214-228.

(2014b).

Do Business Characteristics Determine an Effective Tax Rate? The Chinese Economy, 45:6, 60-83.

Saputro, W. (2015). Tax Haven Senjata ampuh mematikan negara berkembang. Indonesian Tax Review., Dwimingguan, Vol. VIII, Edisi 08, 48-51.

Sari, D. K., \& Martani, D. (2010). Karakteristik Kepemilikan Perusahaan, Corporate Governance, dan Tindakan Pajak Agresif. Simponsium Nasional Akuntansi 13, No.11.

Scott, W. R. (2012). Financial Accounting Theory. Sixth Edition. United State: Pearson.

Sekaran, U., \& Bougie, R. (2013). Research Methods for Business:A SkillBuilding Approach. Sixth Edition. United Kingdom: John Wiley \& Sons, Inc.

Subramanyam, K. (2014). Financial Statement Analysis. New York: McGraw Hill Education.

Sulistiawan, D., Januarsi, Y., \& Alvia, L. (2011). Creative Accounting.
Mengungkap Manajemen Laba dan Skandal Akuntansi. Jakarta: Salemba Empat.

Suryowati, E. (2016, April 06). www.kompas.com. Dipetik Januari 18, 2018, dari http://ekonomi.kompas.com/read/201 6/04/06/203829826/Terkuak.Modus. Penghindaran.Pajak.Perusahaan.Jasa. Kesehatan.Asal.Singapura

Suyanto, K., \& Supramono. (2012). Likuiditas, Leverage, Komisaris Independen, Dan Manajemen Laba Terhadap Agresivitas Pajak Perusahaan. Jurnal Keuangan dan Perbankan 16, Hal 167-177.

Tampubolon, M. (2013). Manajemen Keuangan (Finance Management). Jakarta: Mitra Wacana Media.

Tiaras, I., \& Wijaya, H. (2015). Pengaruh Likuiditas, Leverage, Manajemen Laba, Komisaris Independen Dan Ukuran Perusahaan Terhadap Agresivitas Pajak. Jurnal Akuntansi, Vol. XIX, No. 03, p:380-397.

Undang-Undang Republik Indonesia Nomor 28 Tahun 2007 Tentang Perubahan Ketiga Atas UndangUndang Nomor 6 Tahun 1983 Tentang Ketentuan Umum Dan Tata Cara Perpajakan.

Undang-Undang Republik Indonesia Nomor 36 Tahun 2008 Tentang Perubahan Keempat Atas UndangUndang Nomor 7 Tahun 1983 Tentang Pajak Penghasilan.

Undang-Undang Republik Indonesia Nomor 40 Tahun 2007 Tentang Perseroan Terbatas.

www.idx.co.id

Yusuf, O. (2016, September 20). www.kompas.com. Dipetik April 2016, 17, dari https://tekno.kompas.com/read/2016/ 09/20/10330087/cara.google.memanf aatkan.celah.untuk.menghindari.paja $\mathrm{k}$

Zemzem, A., \& Ftouhi, K. (2013). The Effects of Board of Directors' Characteristics on Tax Aggressiveness. Research Journal of Finance and Accounting, 4(4), 140$147 .$. 